\title{
Criteria of Selecting Bank in Pakistani BANKING SECTOR: STUDY OF BANKING Customers in Sahiwal, Pakistan
}

\author{
Bushra Zulfiqar ${ }^{1 *}$, Dr. Hafiz Muhammad Arshad ${ }^{2}$, Zeeshan Fareed ${ }^{2}$, \\ Farrukh Shahzad $^{3}$, Shahbaz Hussain ${ }^{4}$ \\ ${ }^{1}$ University of the Punjab, Lahore, Pakistan \\ ${ }^{2}$ Department of Management Sciences, COMSATS Institute of Information Technology, \\ Sahiwal, Pakistan \\ ${ }^{3}$ Department of Management Sciences, Lahore Leads University, Pakistan \\ ${ }^{4}$ Department of Management Sciences, University of Education, Multan Campus, \\ Pakistan
}

\begin{abstract}
This study is designed to evaluate the customer's behavior towards the bank selection in Sahiwal Division, Pakistan. Questionnaire is used as instrument to measure the bank selection criteria and distributed to 150 respondents of the nationalized (Bank of Punjab), privatized (United Bank Ltd.) and private bank (Bank Alfalah Ltd.) in Sahiwal. Eight factors including 34 attributes on 5 point Likert scale were used to determine the criteria of selecting bank. Frequency table of demographic variables, descriptive statistics of 8 factors and one sample t-test for testing hypothesis are used by SPSS version 16.0 to analyze the customer's bank selection criteria. Eight hypotheses were developed from the literature out of which three were found to be significant. These three factors are "convenience", "quality of services" and "price and cost”.
\end{abstract}

\section{KEYWORDS}

Bank selection criteria, Structural factors, Easy banking process, Pakistan

\section{INTRODUCTION}

The corporate and commercial banking activities have gained more position in Pakistan since last decade. There is a considerable change in Pakistani banking atmosphere due to the advancement in technology, regulatory and structural factors which resulted an increased competition in market. The big competition that exists in Pakistani banking industry offered a big challenge in terms of profitability which depends upon the better product and services being provided by the banks to their customers (Hedayatnia, Eshghi and Avenue, 2011).

The issue regarding "how the customer would select bank" has been a great attention by some researchers (Almossawi , 2001) and exploring this question will enable banks to prepare some banking marketing strategies to invite the new customers and retain existing customers (Kaynak and Kucukemiroglu, 1992). It has been observed from the literature that studies regarding bank selection criteria mostly conducted in the region of USA and some countries of Europe (Denton and Chan, 1991) and few studies are conducted in Pakistan. Although these studies have been playing a vital role in bank selection criteria but the findings of the studies are not applicable to other countries of the world due to the difference in cultures, customs and legal atmosphere. The studies related to bank selection criteria are very few in the region of Gulf area (Saudi Arabia, 
UAE, Kuwait, Qatar, Bahrain and Oman) which is called most wealthy region in the world. (Azzam, 1989).

Rehman and Ahmed (2008) have conducted a study regarding bank selection criteria in the city of Lahore. According to their analysis, Convenience and Customer services are most important determinants. They also revealed in their study that a big change in banking sector of Pakistan has been occurred since last 15 years. It has changed from less competitive to more competitive sector. Mergers and acquisition activities are increasing in Pakistani banking sector which also increases the market competitive pressure. Pakistan allowed some foreign banks which are acquiring some smaller banks of Pakistan with a comprehensive branch network. All of these changes created a big challenge for Pakistani banks to make their customers "loyal" by providing good services and facilities with the help of banking marketing strategies.

Earlier, (Awan and Bukhari, 2011) conducted research on criteria for selecting an Islamic bank in Pakistan and stated that customers select Islamic banks on the basis of quality services and give minor importance to the religious beliefs while selecting Islamic bank.

Nayyab, et al. (2011) conducted the research on Islamic bank selection criterion and related it to customer's demographic factors in Okara city (Pakistan). They stated that customer choose the Islamic bank by giving first preference to convenience and second preference to cost and benefit criterion.

In this study, we have made efforts to develop the bank selection criteria by taking evidence from the customers of Nationalized bank (Bank of Punjab), privatized bank (United Bank Limited) and private bank (Bank Alfalah Limited) in Sahiwal city.

\subsection{The objectives of the study}

1. To define the factors (criteria) that customer adopts while selecting a bank.

2. To determine the factors which are prioritized by customers of nationalized bank, privatized bank and private bank.

3. To identify the significant difference among the customers of nationalized, privatized and private bank in terms of bank selection.

\section{REVIEW OF LITERATURE}

Literature shows that plenty of research has been conducted on the bank selection criteria in different countries of the world.

So the literature is reviewed according to the continents of the world.

\subsection{Criteria of bank selection in Europe}

Lewis (1982) evaluated the behavior of college students in terms of bank selection. For this purpose he surveyed 716 students from 11 colleges and universities in England. The result revealed that "convenient of location to college" and "parental advice and influence" were found to be important factors in this regard.

Holstius and Kaynak (1995) surveyed 258 Finish banking customers in terms of bank selection criteria and results indecated that the Finish customers select the bank on the basis of these important factors ranked respectilvely: "fast and efficient services", "reception at the bank", "friendliness of personnel", "lower service charges" and "perceived confidentiality". 
Mylonakis, Malliaris and Siomkos (1998) conducted the research on banking customers to find out the taste and criteria to select the bank on the basis of some factors in Greece. They used sample of 811 banking customers and the result revealed that the most important factors were ranked as "convenient location" and "quality of services (personalized service, no queues, attention to customers)".

Kennington, Hill and Rakowska (1996) studied the consumer selection for bank in Poland. They collected the data from 204 ploish respondents. The findings revealed that the reputation and pricing were the most important variables for bank selection in Poland.

Thwaites and Vere (1995) conducted the reseach to evaluate the bank selection criteria through college students in Britain and "ATM nearness to university" and "free banking services" were found to be high in rank in term of bank selection criteria.

\subsection{Criteria of bank selection in Africa}

Bick, Brown and Abratt (2004) surveyed the retail banking customers in South Africa to check the anticipation and perception about the retail banking customers regarding services and values given them by retail banks. The findings revealed that the customers were not fully satisfied with the services, offered by retail banks according to their expectations.

Omer and Orakwue (2006) investigated the bank selection criteria used by customers in Nageria. The result stated that the important factors were considered by Nagerian customers for selection of bank and these factors were ranked in this sequence "safety of fund", "efficient of service" and "speed of transaction"

Hinson, Owusu-Frimpong and Dasah (2009) investigated the bank selection choice in Ghana. They used the sample of 2000 customers of 22 retail banks in Ghana. The factor "Proximity" was highly recommended by customers in term of bank selection and the "word of mouth advertising" was the least ranked factor recommended by customers.

\subsection{Criteria of bank selection in North and South America}

The study related to bank selection decision was conducted in USA by (Kaufman, 1967) checked the factors which effect on bank selection by household, customers and firms operating in the USA. He revealed that household selects the bank on the basis of these variables like quality of services, relationship between bank and customers and suitable location to home offered by bank.

Mason and Mayer (1974) conducted the research on bank selection by two groups of customers with low income and high income in the region of USA. He found that "conveneint" factor is the top in rank and other factors were priorities in this sequence: "friendly personnel", "favourable loan experience", "advice of friends", and "influence of relatives".

This study was conducted in USA by Javalgi, et al. (1989) and investigated that bank selection decision were influenced by monetry factors. The findings showed that financial factors like "interest on savings accounts", "safty of funds" and "availability of loans" were having high scores. Some other important factors were "convenient location" and "bank's reputation".

Khazeh and Decker (1993) checked the view of 209 students of universities, in term of bank selection choice, in Maryland, USA. The findings showed the most important factors which 
influence students for bank selection: "service charge policy", "reputation", "interest charged on loans", "quick loan approval and friendly tellers".

Boyd, Leonard and White (1994) investigated the bank selection criteria on the basis of age of the household head by using telephone survey in USA. They stated that the persons having the age under 21 years recommended the factor "reputation" out of ten in top priority for bank selection and followed by "location", "hours of operation", "interest on savings accounts", "the provision of convenient" and "quick services". The least ranked factors for bank selection criteria were to be found "friendliness of bank employees" and "the modern nature of their facilities".

Yue and Tom (1995) determined the bank selection criteria through Chinese-American banking customers in the region of Sacramento, California USA. The important factors were ranked by customers in term of bank selection criteria in this way: "efficiency of services offered", "bank's reputation", "bank fees", "convenient location", and "interest rates on saving accounts and loans".

Blankson, Ming-sung and Spears (2007) checked the bank selection choice/criteria through customers in term of cultural and economic scenario of USA, Ghana and Taiwan. The results showed that there is no difference in bank selection criteria by customers of USA, Ghana and Taiwan.

Pass (2006) studied the bank selection criteria by some college students. He used a sample of 373 students from 4 colleges and universities in Western US to investigate what are the important variables on which students select the banks. Findings revealed that "pricing" and "convenience" were found to be suitable factors in selection of a new bank.

Laroche, Rosenblatt and Manaing (1986) tested 140 households in Canada to analyze that how customers select the bank in competitive banking atmosphere. The result revealed that "friendliness of staff" was having the important role in the process of bank selection and some other factors were ranked according to their importance in this sequence "hours of operation", "size of waiting lines", "convenience of location" and "efficiency of personnel".

\subsection{Criteria of bank selection in Oceania/Australia}

The nationwide survey is conducted by Nielsen, et al.(1998) to evaluate the bank selection behavior of customers in Australia. They used the sample of 2500 from 25 banks. Results showed that the business customers strongly recommended those factors which full fill their credit needs.

\subsection{Criteria of bank selection in Asia}

According to (Kaynak and Kucukemiroglu, 1992) who conducted the research in Hong Kong to check how the customers of domestic and foreign banks make significant choice of bank. Findings showed that the real factors like "convenient location", "financial counseling", "and available parking space nearby", "vault location", "loans and mortgages" were prioritized by customers.

Tan and Chua (1986) investigated the customer behavior towards the bank selection in Singapore through selecting randon sample and stated that "third party influence" namely bank recommended by family and bank recommended by friends were both top in rank in selecting 
bank and "convenience of location" was ranked in middle, while "speed of service delivery" was low in rank.

Haron, Ahmed and Planisek (1994) surveyed 301 Malaysian customers of commercial banks in two groups Muslims and non-Muslims to identify the bank selection criteria. The result revealed that the highest ranked factors were: "speed of transactions", "fast and efficient services", "friendliness of bank personnel", and "confidentiality of bank".

Mokhlis, Mat and Salleh (2008) surveyed the undergraduates to check the bank selection behavior of University students in Malaysia. They take University Malaysia Terengganu as sample and these factors "secure feelings", "ATM service and financial benefits" were found to be important factors which influenced the undergraduates.

Erol , Kaynak and El-B (1990) conducted the research on bank selection by Islamic and conventional bank's customers in Jordon. The result described the highly ranked factors namely "fast and efficient services", "confidentiality of bank", "bank reputation and image" and "friendliness of bank personnel".

This study was conducted in Bahrain by Al-Ajmi, Abo Hussain and Al-Saleh (2009) to investigate the bank selection choice. They filled the 1000 questionnaires form customers of Islamic and conventional banks with response rate of 65.5 and the results revealed that the most important factors were ranked "Islamic religious belief" and "social responsibility" by Bahrainian customers and the factor "cost benefit" was ranked in third.

Almossawi (2001) investigated the bank selection choice by university students in Bahrain. He used the sample of 1000 students of university of Bahrain having the age between 19-24 and results revealed some factors according to their importance by university students in this sequence of priority: "bank's reputation", "friendliness of bank personnel", "availability of parking space near the bank", "availability of ATM" and "location of ATM (automated teller machines)".

Rashid (2009) conducted the research to analyzed the Islamic bank selection criteria in Bangladesh. He used sample of 371 customers from 5 banks in Dhaka capital city. The factors like "corporal efficiency", "core-banking services" and "confidence" were found to be important in bank selection criteria by Bangladeshian banking customers.

Hedayatnia, Eshghi and Avenue (2011) studied to check the bank selection criteria of retail banking industries in Iran with 38 factors. They took the sample of 798 banking customers and interviewed the 5 officials of bank. They used the factor analysis and Friedman analysis to check the bank selection criteria. The results revealed that "quality of services and new banking methods", "innovation and responsiveness of bank", "friendliness of staff and confidence in manager", "price and cost", "staff attitudes" and "convenience of bank location and services" were the factors ranked by students for select the bank.

Rao and Sharma (2010) surveyed MBA students of colleges to check the bank selection criteria in India. They collected the data from 312 students who were having bank accounts and the results indicate that "reliability" is found to be most important factor by student in term of bank selection. The other important factors were ranked respectively "responsiveness" and "convenience".

Rehman and Ahmed (2008) conducted the research on bank selection criteria in Lahore, Pakistan. They collected the data from 358 customers of privatized, nationalized and private banks in Lahore. The findings revealed that such factors like "customer services", 
"convenience", "online banking facilities" and "overall bank environment" were prove to be most important for bank selection.

Awan and Bukhari (2011) studied to evaluate the Islamic bank selection criteria in Pakistan. They used the sample size of 250 respondents and results showed that the customers highly value these factors "product features" and "quality of services" according to their importance while "religious belief" is less important for selection of an Islamic bank.

Nayyab, et al. (2011) checked the impact of demographic variables on Islamic bank selection criteria in Okara, Pakistan. They collected the data from 100 respondents who were having the bank accounts of three Islamic banks "Dubai Islamic Bank Ltd.", "Islamic Bank Ltd.", and "Meezan Bnak Ltd.". The result indicated that the "convenience" is the first most important factor while "corporal efficiency" and "cost and benefit" are the second most important factors for bank selection. The least important factor was found to be "compliance".

All the studies mentioned above the bank selection criteria by customers of different continents of the world. Driscoll (1999) described in his study that the customers select bank on the basis of these five factors respectively, "convenience", "price", "product selection", "service" and "customer experience".

\subsection{Research gap}

Prior to this study, one research is conducted by Nayyab, et al. (2011) who determined the impact of demographic variables on Islamic bank selection criteria in Okara city of Pakistan. The other research is conducted by Rehman and Ahmed (2008) to check the bank selection criteria from the customers of private, nationalized and privatized banks in Lahore city. They considered five factors are most important i.e. "online banking facility", "profit rate", "banks internal environment and external appearance", "convenience" and "accessibility". This study is conducted to determine the bank selection criteria by customers of nationalized bank (Bank of Punjab), privatized bank (United bank Ltd.) and private bank (Bank Alfalah Ltd.) in Sahiwal city by taking 8 factors consisted of 34 evaluative criteria on 5 point Likert scale.

\section{TheORETICAL FrameWORK}

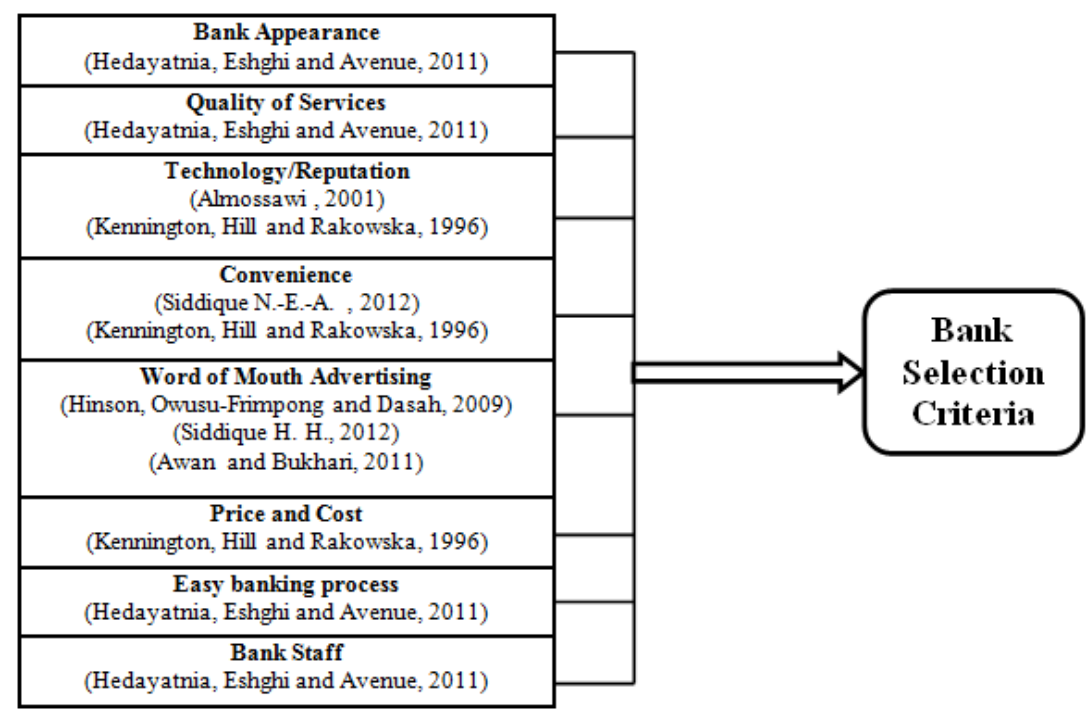

Figure 1. Graphical research model 
The above model is derived from the various studies and the following hypotheses were constructed on the basis of above research model.

\begin{tabular}{|l|l|}
\hline $\mathrm{H}_{1}$ & Bank appearance effects on customer's bank selection \\
\hline $\mathrm{H}_{2}$ & Quality of services effects on customer's bank selection \\
\hline $\mathrm{H}_{3}$ & Technology/Reputation effects on customer's bank selection \\
\hline $\mathrm{H}_{4}$ & Convenience effects on customer's bank selection \\
\hline $\mathrm{H}_{5}$ & Word of mouth advertising effect on customer's bank selection \\
\hline $\mathrm{H}_{6}$ & Price and cost effect on customer's bank selection \\
\hline $\mathrm{H}_{7}$ & Easy banking process effects on customer's bank selection \\
\hline $\mathrm{H}_{8}$ & Bank staff effects on customer's bank selection \\
\hline
\end{tabular}

\section{Methodology}

\subsection{Method of data collection}

Questionnaire was used as instrument to identify the bank selection criteria, extracted from various relevant studies. Questionnaire was divided into two parts, one part show the demographic variables and 2nd part show the 8 factors consisted of 34 different attributes which were considered to be very supportive for bank selection. The scale of 5 point Likert ranging from "strongly disagree" to "strongly agree" was used. Questionnaires were distributed to 175 respondents out of which 168 were returned and 150 were considered valid and completed, representing the response rate of 85.71 percent.

Convenience (non-probability) sampling was used due to nature of study and time constraint. The population is consisted of all the active customers of three banks, Bank of Punjab (Nationalized bank), United Bank Ltd. (Privatized bank) and Bank Alfalah Ltd. (Private bank) in Sahiwal city.

\subsection{Method of data analysis}

Statistical Package for Social Sciences (SPSS) version 16.0 was used to analyze and interpret the data. In this study, Descriptive and inferential statistics were used to analyze the data. Frequency of demographic variables is measured. Mean of 8 factors were calculated and ranked according to their importance. One sample t-test was used to test the research hypothesis and to attain the objectives of the study.

\section{FINDINGS (RESULTS AND INTERPRETATION)}

Table 1 Demographic Variables

\begin{tabular}{|l|c|c|}
\hline \multicolumn{1}{|c|}{ Gender } & Frequency & Percent \\
\hline Male & 96 & 64.0 \\
\hline Female & 54 & 36.0 \\
\hline Total Age & 150 & 100.0 \\
\hline \multicolumn{1}{|c|}{ Frequency } & Percent \\
\hline Under 20 Years & 48 & 32.0 \\
\hline 20-24 Years & 54 & 36.0 \\
\hline 25-28 Years & 13 & 8.7 \\
\hline More than 28 years & 35 & 23.3 \\
\hline
\end{tabular}


International Journal of Managing Value and Supply Chains (IJMVSC) Vol. 5, No. 4, December 2014

\begin{tabular}{|c|c|c|}
\hline Total & 150 & 100.0 \\
\hline Marital Status & Frequency & Percent \\
\hline Single & 81 & 54.0 \\
\hline Married & 69 & 46.0 \\
\hline Total & 150 & 100.0 \\
\hline Education Level & Frequency & Percent \\
\hline Illiterate & 34 & 22.7 \\
\hline Matric & 77 & 51.3 \\
\hline Intermediate & 28 & 18.7 \\
\hline Bachelors & 8 & 5.3 \\
\hline Masters & 3 & 2.0 \\
\hline Total & 150 & 100.0 \\
\hline Bank Name & Frequency & Percent \\
\hline Bank Alfalah Ltd. & 62 & 41.3 \\
\hline United Bank Ltd. & 51 & 34.0 \\
\hline Bank Of Punjab & 37 & 24.7 \\
\hline Total & 150 & 100.0 \\
\hline Account Type & Frequency & Percent \\
\hline Current Account & 61 & 40.7 \\
\hline Saving Account & 37 & 24.7 \\
\hline Fixed deposit Account & 52 & 34.7 \\
\hline Total & 150 & 100.0 \\
\hline
\end{tabular}

Table- 1 shows that out of total 150 respondents the male were $96(64 \%)$ and the female were 54 (36\%). There were $48(32 \%)$ respondents with the age under 20 years, $54(36 \%)$ were having the age between $20-24$ years, 13 (8.7\%) were having the age between 25 -28 years, and $35(23.3 \%)$ respondents with age more than 28 years. Out of 150 respondents, 81(54\%) were the single and $69(46 \%)$ were the married. Out of 150 respondents, illiterate were $34(22.7 \%)$, matric qualified were $77(51.3 \%)$, intermediate qualified were $28(18.7 \%)$, graduates were $8(5.3 \%)$ and the masters were only $3(2 \%)$. The $62(41.3 \%)$ respondents were from Bank Alfalah Ltd., 51(34\%) from United Bank Ltd. and 37 (24.7\%) were from the Bank of Punjab. Out of 150 respondents, current account holders were 61 (40.7\%); saving account holders were $37(24.7 \%)$ and fixed deposit account holder were $52(34.7 \%)$.

\subsection{Hypothesis Testing}

Table 2 One-Sample Statistics (Test Value=4)

\begin{tabular}{|c|c|c|c|c|c|c|}
\hline Factors & N & Mean & Std. Deviation & $\begin{array}{c}\text { Std. Error } \\
\text { Mean }\end{array}$ & t-value & p-value \\
\hline Bank Appearance & 150 & 3.9250 & .49642 & .04053 & -1.85 & 0.967 \\
\hline Quality of Services & 150 & 4.1493 & .42486 & .03469 & 4.30 & $0.000^{*}$ \\
\hline
\end{tabular}


International Journal of Managing Value and Supply Chains (IJMVSC) Vol. 5, No. 4, December 2014

\begin{tabular}{|l|c|c|c|c|c|c|}
\hline $\begin{array}{l}\text { Technology/Reputati } \\
\text { on }\end{array}$ & 150 & 3.6783 & .85743 & .07001 & -4.60 & 1.000 \\
\hline Convenience & 150 & 4.3401 & .61710 & .05039 & 6.75 & $0.000 *$ \\
\hline Advertising & 150 & 3.1733 & .91773 & .07493 & -11.03 & 1.000 \\
\hline Price and Cost & 150 & 4.1437 & .52790 & .04310 & 3.33 & $0.001 *$ \\
\hline Easy banking process & 150 & 2.9633 & .83515 & .06819 & -15.20 & 1.000 \\
\hline Bank staff & 150 & 3.2707 & .75089 & .06131 & -11.90 & 1.000 \\
\hline
\end{tabular}

Significant at: ${ }^{*} \mathrm{p}<0.01$

Table-II shows that "convenience" is very important factor in bank selection process by customers as the mean value of its 4.34 which is consider significant by perception of respondents because its mean is greater than the test value( $4=$ level of agreement) $4.34>4$ or $p$ value $0.000<.01$. While "Quality of services" is also significant by the perception of customers because its mean value (4.15) is greater than the test value $4.15>4$ (4=level of agreement) or pvalue $0.000<.01$. The factor "price and cost" is also found to be significant by respondent's perception because its mean value (4.14) is also greater than the test value (4=level of agreement) i.e. $4.14>4$ or p-value $0.001<.01$. The factor "bank appearance" having the mean value 3.92 which is very close to test value (4=level of agreement) so, up to the some extent it can also be consider that "bank appearance" is important for the bank selection by the perception of respondents.

On the basis of these findings we are fail to reject our three research hypothesis i.e. H4: Convenience effects on customer's bank selection, H2: Quality of services effects on customer's bank selection and H6: Price and cost effect on customer's bank selection.

The hypothesis $\mathrm{H} 1, \mathrm{H} 3, \mathrm{H} 5, \mathrm{H} 7$ and $\mathrm{H} 8$ are not statistically significant by the customer's perception. It means that factors like "bank appearance", "technology", "word of mouth advertising", "easy banking process" and "bank staff" are not influenced more by customers while bank selection in Sahiwal city.

Table 3 Rank of Factors

\begin{tabular}{|c|l|c|}
\hline \multicolumn{1}{|c|}{ Factors } & Mean Rank \\
\hline \multirow{5}{*}{ Factor 4 } & \begin{tabular}{l}
\multicolumn{1}{|c|}{ Bank is located at convenient location for customer } \\
Convenient location of the main branch \\
Hours of operation \\
Available parking space nearby \\
Non-stop Banking
\end{tabular} & 4.34 \\
\hline Convenient ATM location 2 & $\begin{array}{l}\text { Accuracy of services Transactions } \\
\text { Quality of Customer Services } \\
\text { Provision of fast and efficient service } \\
\text { Availability of different types of new banking methods }\end{array}$ & 4.15 \\
\hline Factor 6 & $\begin{array}{l}\text { Reduction of queuing time } \\
\text { Bank charges competitive prices for products and services } \\
\text { Paying highest interest rates on saving accounts } \\
\text { Low Interest rates on Loan }\end{array}$ & 4.14 \\
\hline
\end{tabular}




\begin{tabular}{|c|l|c|}
\hline \multirow{2}{*}{ Factor 1 } & $\begin{array}{l}\text { External Appearance of Bank } \\
\text { Interior Design of Bank } \\
\text { Pleasant bank atmosphere and sufficient facilities } \\
\text { Sitting arrangements }\end{array}$ & 3.93 \\
\hline Factor 3 & $\begin{array}{l}\text { ATM in Several Locations } \\
\text { Bank has a strong reputation and good image in the community } \\
\text { 24 hours ATM Service } \\
\text { Home Banking }\end{array}$ & 3.68 \\
\hline \multirow{2}{*}{ Factor 8 } & $\begin{array}{l}\text { Appearance and attire of Staff } \\
\text { Knowledgeable and Competent Staff } \\
\text { Ease of obtaining Loan } \\
\text { Friendliness of bank staff } \\
\text { Confidence in bank Manager }\end{array}$ & 3.27 \\
\hline \multirow{2}{*}{ Factor 5 } & $\begin{array}{l}\text { Bank recommended by Friends } \\
\text { Bank recommended by Relatives }\end{array}$ & 3.17 \\
\hline \multirow{2}{*}{ Factor 7 } & $\begin{array}{l}\text { Advertisement } \\
\text { Ease of opening an Account } \\
\text { Ease of obtaining Loan } \\
\text { Availability of different Banking Cards }\end{array}$ & 2.96 \\
\hline
\end{tabular}

Factors are ranked according to their mean value, factor 4 "convenience" has the maximum value of mean (4.34), which means that respondents are agree with these attributes like convenient ATM location, accuracy of services transactions, quality of customer services and provision of fast and efficient services in bank selection criteria and the factor 7 "easy banking process" has the least value of mean (2.96) which means that respondents are disagree about these attributes like advertisement, ease of opening of account, ease of obtaining loan, and availability of different banking cards in term of bank selection criteria.

Some others important factors are in sequence like factor 2 "quality of services" having the mean 4.15 , factor 6 "price and cost" having the mean value of 4.14, factor 1 "bank appearance" having the mean value 3.93, factor 3 "technology" having the mean value 3.68, factor 8 "bank staff" having the mean value of 3.27 and factor 5 "advertising" having mean 3.17.

The top four factors "convenience", "quality of services", "price and cost" and "bank appearance" play very important role for customer's bank selection process and these finding resemble to the findings of these prior studies (e.g. Mylonakis et al., 1998; Mason et al., 1974; Pass, 2006; Kaynak et al., 1992; Hedayatnia et al., 2011; Rao et al., 2010; Rehman et al., 2008; Awan at el., 2011). The factors "reputation" and "word of mouth advertising" are very significant for bank selection decision by bank customers of other studies; Pakistani's banking customer overlooked these two factors. This study's findings different to findings of some other studies ( e.g. Almossawi , 2001; Yue et al., 1995; Hedayatnia et al., 2011; Hinson et al., 2009; Khazeh et al., 1993; Erol et al., 1990; Javalgi et al., 1989; Mason et al., 1974; Tan et al., 1986) which highlights the "reputation/technology" and "word of mouth advertising" are important factors for bank selection process by customers. There is no similar research conducted in Sahiwal city of Pakistan and we can compare the finding of this study to with the finding of some studies conducted in neighboring countries. The people of Pakistan have some communal cultural heritages with the people in Iran and Bahrain. So, the banking customers of Middle East having similar decision of bank selection practice. The two factors "convenience" and "quality of services" are both common factors for bank selection by Pakistani and Iranian banking customers (Hedayatnia, Eshghi and Avenue, 2011) but the factor "price and cost" is consider very important by Iranian banking customer while less important by Pakistini banking customers (Rehman and Ahmed, 2008). The factor "Convenient" is consider common and highly ranked by pakistani's and Bahrainian banking customers while factor "reputation/technology" is found 
to be little different by pakistani and Bahrainian banking customers (Hedayatnia, Eshghi and Avenue, 2011).

\section{CONCLUSION AND RECOMMENDATIONS}

The aim of this study is to find some important factors as the customers think that suitable for bank selection in Sahiwal city. This study is seen to be very important in both practical and theoretical point of views. Theoretically, it fills the gap in literature by exploring the bank selection decisions by customers in Sahiwal city. The findings of the study will also prove very helpful and supportive for future researchers in term of bank selection criteria by providing a wide knowledge in literature of bank marketing. Practically, this study will help to bank managers in identifying such important factors among customers in term of bank selection. The findings of the study will also assist the management of the bank for making such policies criteria, and marketing strategies which will be fruitful for increasing attraction and retaining existing customers.

The results of this study revealed that three factors i.e. "convenience", "quality of services" and "price and cost" are very important for bank selection in Sahiwal city, Hence, the management of nationalized, privatized and privates banks should keep in view these important factors while making marketing strategies.

This study shows that maximum respondents are young's (36\%) having the age between 20-24 years and such customers like new technologies in their daily routines so, bank managers should provide "internet banking", "mobile banking" and "email banking" for attracting and retaining existing customers.

Finally, today's the personalized and value added services like e-banking are demanding by customers because they do not like to visit the bank branches due to time constraint. So, the bank management should understand the needs of their customers by providing these e-banking facilities to retaining their customers.

\section{REFERENCES}

1. Al-Ajmi, J., Abo Hussain, H. and Al-Saleh, N. (2009). Clients of conventional and Islamic banks in Bahrain: How they choose which bank to patronize. International Journal of social Economics, 36(11).

2. Almossawi , M. (2001). Bank selection criteria employed by college students in Bahrain: an empirical analysis. International Journal of Bank Marketing, 19(3), 155-125.

3. Awan, H. M. and Bukhari, K. S. (2011). Customer's criteria for selecting an Islamic bank: evidence from Pakistan. Journal of Islamic Marketing, 2(1), 14-27.

4. Azzam, H. (1989). Gulf News. Supplement, 1 April, p. 3.

5. Bick, G., Brown, A. and Abratt, R. (2004). Customer perceptions of the value delivered by retail banks in South Africa. International Journal of Bank Marketing, 25(5), 300-318.

6. Blankson, C., Ming-sung, C. J. and Spears, N. (2007). Determinants of banks selection in USA, Taiwan and Ghana. International Journal of Bank Marketing, 25(7), 469-489.

7. Boyd, W., Leonard, M. and White, C. (1994). Customer preferences for financial services: an analysis. International Journal of Bank Marketing, 12(1), 9-15.

8. Denton, L. and Chan, A. (1991). Bank selection criteria of multiple bank users in Hong Kong. International Journal of Bank Marketing, C9(4), 23-34.

9. Driscoll, J. (1999). Bank wars: episode 2. The branches strike back. Bank Marketing, 31(12), 22-30.

10. Erol , C., Kaynak, E. and El-B, d. R. (1990). Conventional and Islamic banks: patronage behavior of Jordanian customers. International Journal of Bank Marketing, 8(4), 25-35.

11. Haron, S., Ahmed, N. and Planisek, S. (1994). Bank patronage factors of Muslim and non-Muslim customers. International Journal of Bank Marketing, 12(1), 32-40. 
12. Hedayatnia, A., Eshghi, K. and Avenue, G. (2011). Bank Selection Criteria in the Iranian Retail Banking Industry. International Journal of Business and Management, 6(12), 222-231.

13. Hinson, R., Owusu-Frimpong, N. and Dasah, J. (2009). Key motivations for bank patronage in Ghana. International Journal of Bank Marketing, 27(5), 381-399.

14. Holstius, K. and Kaynak, E. (1995). Retail banking in Nordic countries: the case of Finland. International Journal of Bank Marketing, 13(20), 10-20.

15. Javalgi, R., Armaco, R. and Hosseini, J. (1989). Using the analytical hierarchy process for bank management: analysis of consumer selection decisions. Journal of Business Research, 19, 33-49.

16. Kaufman, G. G. (1967). A Survey of Business Firms and Households View of a Commercial Bank. University of Wisconsin, Madison, WI. Report to the Federal Reserve Bank of Chicago, Appleton.

17. Kaynak, E. and Kucukemiroglu, O. (1992). Bank and product selection: Hong Kong. International Journal of Bank Marketing, 10(1), 3-16.

18. Kennington, C., Hill, J. and Rakowska, A. (1996). Consumer selection criteria for banks in Poland. International Journal of Bank Marketing, 14(4), 12-21.

19. Khazeh, K. and Decker, W. (1993). How customers choose banks. Journal of Retail Banking, 14(4), 92-93.

20. Laroche, M., Rosenblatt, J. and Manaing, T. (1986). Services used and factors considered important in selecting a bank: an investigation across diverse demographic segments. International Journal of Bank Marketing, 4(1), 35-55.

21. Lewis, B. R. (1982). Student accounts \pm a profitable segment? European Journal of Marketing, 16(3), 63-72.

22. Mason, J. and Mayer, M. (1974, June). Differences between high-and-low-income savings and checking account customers. The Magazine of Bank Administration, 65, 48-52.

23. Mokhlis, S., Mat, N. H. and Salleh, H. S. (2008). Commercial Bank Selection: The Case of Undergraduate Students in Malaysia. International Review of Business Research Papers, 4(5), 258270.

24. Mylonakis, J., Malliaris, P. and Siomkos, G. (1998). Marketing-driven factors influencing savers in the hellenic bank market. Journal of Applied Business Research, 14(2), 109-116.

25. Nayyab, H. H., Sehr, A., Adnan, M. and ALi, Z. (2011). Impact of customer demographics on bank selection criteria-A study of banking sector of Okara, punjab (Pakistan). Interdiciplinary Journal of Contemporary Research In Business, 3(2), 773-789.

26. Nielsen, James, F., Chris , T. and Rowan, M. T. (1998). Business banking in Australia: A comparison of expectations. International Journal of Bank Marketing, 16(6), 253-263.

27. Omer, O. and Orakwue, E. (2006). Gender-based choice of retail banking in Nigeria. Journal of Business and Retail Management Research (JBRMR).

28. Pass, M. W. (2006). Western US college students: banking preferences and marketplace performance. Journal of Financial Services Marketing, 11, 49-63.

29. Rao, S. and Sharma, R. K. (2010). Bank Selection Criteria Employed by MBA Students in Delhi: An Empirical Analysis. Journal of business studies Quarterly, 1(2), 56-69.

30. Rashid, M. (2009). Customer Demographics Affecting Bank Selection Criteria, Preference, and Market Segmentation: Study on Domestic Islamic Banks in Bangladesh. International journal of Business and Management, 4(6).

31. Rehman, H. U. and Ahmed, S. (2008). An empirical analysis of the determinants of bank selection in pakistan a customer view. Pakistan Economic and Social Review, 46(2), 147-160.

32. Siddique, H. H. (2012). Bank selection decision criteria employed by indian expatriates in sultanate of oman: an empirical analysis. International Journal of Business And Management Studies, 4(2), 55-64.

33. Siddique, N.-E.-A. (2012). Bank Selection Influencing Factors: A Study on Customer Preferences with Reference to Rajshahi City. Asian Business Review, 1(1), 80-87.

34. Tan, C. and Chua, C. (1986). Intention, attitude and social influence in bank selection: a study in an oriental culture. International Journal of Bank Marketing, 4(3), 43-53.

35. Thwaites, D. and Vere, L. (1995). Bank selection criteria: A student perspective. Journal of Marketing Management, 11(1-3), 133-149.

36. Yue, H. and Tom, G. (1995). How the Chinese selects their banks. Journal of Retail Banking, 16(4). 


\section{About the Authors:}

Bushra Zulfiqar has done Master in Economics from Punjab University, Lahore Pakistan. She has more than 2 years of teaching experience in the field of economics. She has many research publication in international journals.

Dr. Hafiz Muhammad Arshad was ex-statistical Officer in Federal Bureau of Statistics, Government of Pakistan, Islamabad. He is currently working as assistant professor in Comsats Institute of Information Technology, Sahiwal, Pakistan. He is also HEC approved supervisor. He is excellent researcher in the field of statistics.

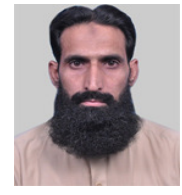

Zeeshan Fareed has done MS/M.Phil in Management sciences with specialization Finane. He has several research publications in the field of management sciences. He has achieved research productivity award 2013 from Comsats Institute of Information Technology, Islamabad, Pakistan.

Farrukh Shahzad is MS/M.Phil (Finance) Candidate in Lahore Leads University, Pakistan. He has more than 2 years of banking experience. He has excellent research expertise in the field of banking and finance. He has several research publications in international Journals.

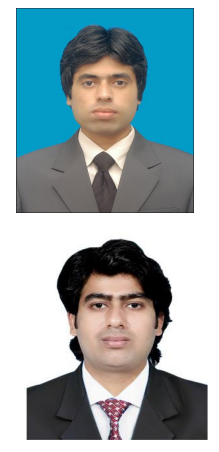

Shahbaz Hussain is currently working as Lecturer in University of Education, Multan Campus, Pakistan. He is MS/M.Phil Candidate with Marketing specialization in NUML, Multan Campus. He has excellent research expertise in field of Marketing.

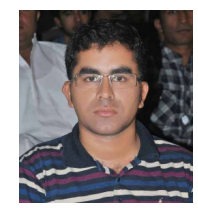

